\title{
Bioavailability of Nutrients in Seeds from Tropical and Subtropical Soybean Varieties
}

\author{
A. Moreira, L. A. C. Moraes, L. G. M. Souza \& I. P. Bruno
}

To cite this article: A. Moreira, L. A. C. Moraes, L. G. M. Souza \& I. P. Bruno (2016) Bioavailability of Nutrients in Seeds from Tropical and Subtropical Soybean Varieties, Communications in Soil Science and Plant Analysis, 47:7, 888-898, DOI: 10.1080/00103624.2016.1146899

To link to this article: https://doi.org/10.1080/00103624.2016.1146899

Accepted author version posted online: 24

Feb 2016.

Published online: 22 Apr 2016.

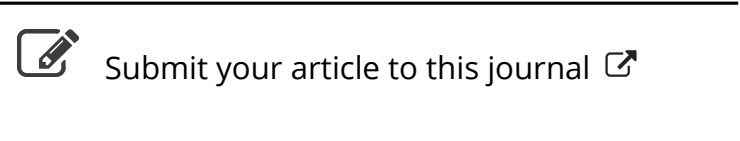

Џll Article views: 82

View Crossmark data ¿

Citing articles: 3 View citing articles $\longleftarrow$ 


\title{
Bioavailability of Nutrients in Seeds from Tropical and Subtropical Soybean Varieties
}

\author{
A. Moreiraa, L. A. C. Moraes ${ }^{\text {b }}$, L. G. M. Souzac, and I. P. Bruno ${ }^{d}$ \\ ${ }^{a}$ Department of Soil Science and Plant Nutrition, Embrapa Soybean, Londrina, Paraná State, Brazil; ${ }^{b}$ Department of \\ Plant Physiology, Embrapa Soybean, Londrina, Paraná State, Brazil; 'Department of Agronomy, São Paulo State \\ University, llha Solteira, São Paulo State, Brazil; 'Department of Agronomy, Agronomic Institute of Paraná - IAPAR, \\ Londrina, Paraná State, Brazil
}

\begin{abstract}
The selection of varieties or species of plants with higher nutrient uptake efficiency and nutrient concentration for biofortification of food crops is a key tool to reduce malnutrition. Soybean (Glycine max L. Merr) is one of the most important food crops, because it is consumed directly or indirectly, in the form of seeds, processed (milk and/or derivatives), or used as a protein component of animal feed worldwide. In order to select plants with higher nutrients concentration in seeds, 24 soybean varieties for tropical and subtropical conditions and different general features were assessed. There was great variability in photosynthesis rate, chlorophyll content, seed yield (SY), and concentration and uptake of nutrients by seeds between the varieties. Not genetically modified (NGM) crops showed higher nitrogen $(\mathrm{N})$, cooper $(\mathrm{Cu})$, and manganese $(\mathrm{Mn})$ concentration and higher $\mathrm{N}$, potassium (K), Cu, iron (Fe), Mn, and zinc ( $\mathrm{Zn}$ ) uptake, while for genetically modified (GM) crops only calcium (Ca) concentrations were higher. Varieties BRS 284 and BMX Magna RR showed the highest nutrients concentrations in the group with the highest nutrient efficiency. The genetic variability observed among the varieties regarding uptake and translocation of nutrients into seeds allows selecting more promising materials to be used in the biofortification of nutrients in soybean seeds.
\end{abstract}

\section{ARTICLE HISTORY}

Received 6 May 2015

Accepted 6 November 2015

\section{KEYWORDS}

Biofortification; essential elements; Glycine max; nutrient concentration; nutrients-use efficiency; nutrient uptake

\section{Introduction}

Being a very versatile source of protein for food uses and also with high market potential (domestic and international markets) and economic benefits, soybean is one of the world's most important agricultural crops (Silva et al. 2006; USDA 2014). Soybean is characterized by high phenotypic plasticity, with crops grown in tropical and temperate regions (Smith and Huyser 1987). World soybean yield in 2013 was 270 million tons of seed: $26.7 \%$ of it was processed into meal and $6.5 \%$ into oil (USDA - United State Department of Agriculture 2014).

Soybean is the main source of protein for animal feed (Krishnan et al. 2011). In human nutrition, soybean is a raw material used in the production of several types of oils, margarine, and vegetable fat. Thus, the relationship between soybean intake and human and animal health has been widely investigated (Krishnan et al. 2011; Silva et al. 2006; Simão et al. 2008). Through the process of purification of refined oil, lecithin is also obtained, which is used in the production of sausages, mayonnaise, ice creams, chocolate products, cereal bars, and frozen products (Mounts, Wolf, and Martinez 1987).

Bioavailability is defined as the proportion of a nutrient that is absorbed and adequately utilized for normal body functions (Fairweather-Tait and Southon 2003). Thus, the consumption of soybean 
and derivatives or its isoflavones has beneficial effects that may act as modulators of metabolic processes, preventing the onset of degenerative diseases such as postmenopausal bone loss and osteoporosis (Childs 1995; Simão et al. 2008). Due to these special features, studies on biofortification and nutrients interactions with vitamins and minerals are needed to support the selection of varieties (Levander and Cheng 1980; Ramamurthy et al. 2014; Welch and Graham 2002). On the other hand, the demand for protein in the form of sausages, meat, and dairy products has increased exponentially in countries with growing per capita income, and, thus, the pressure on livestock and vegetable has also increased, raising soybean costs in developing countries.

Identifying and quantifying the genetic characteristics of plants is an important strategy in the selection for bioavailability of nutrients in seeds, since species and/or varieties may differ significantly in nutrient uptake efficiency and nutrient levels (Fageria, Baligar, and Clark 2002; Ramamurthy et al. 2014; Welch and Graham 2004). Genotypic differences among varieties are manifested as differences in several physiological and biochemical characteristics. To improve food quality, the programs of genetic improvement should conduct studies on the selection of productive plants and/or genetic strategies aimed to ensure higher nutrient quality and levels without negatively impacting crop yield (Fageria, Moreira, and Coelho 2012a; Welch and Graham 2002, 2004).

Given the significant phenotypic variability of soybean varieties produced around the world, with several genetic origins, different nutritional and genotypic features, the present study aimed to assess the concentration and uptake of the macronutrients nitrogen, phosphorus, potassium, calcium, magnesium, and sulfur ( $, \mathrm{P}, \mathrm{K}, \mathrm{Ca}, \mathrm{Mg}$, and $\mathrm{S}$ ) and micronutrient boron, copper, iron, manganese, and zinc ( $\mathrm{B}, \mathrm{Cu}, \mathrm{Fe}, \mathrm{Mn}$, and $\mathrm{Zn}$ ) by seeds of tropical and subtropical soybean varieties of different agricultural and genetic characteristics.

\section{Materials and methods}

The experiment was conducted in greenhouse conditions at Embrapa Soybean, Londrina, Paraná State, Brazil $\left(23^{\circ} 11^{\prime} 39^{\prime \prime} S\right.$ and $\left.51^{\circ} 10^{\prime} 40^{\prime \prime} \mathrm{W}\right)$ with 24 soybean varieties with different growth habits (determinate and indeterminate) transgenic-genetically modified (GM) and non-transgenic-not genetically modified (NGM) (Table 1) that were grown in clay pots with 3.0 liters capacity containing a sandy, kaolinitic, Typic Quartzipsamment soil, with the following chemical properties

Table 1. Description of 24 tropical soybean varieties.

\begin{tabular}{|c|c|c|c|c|}
\hline Varieties & Characteristic & Growing habit & Group maturation & Cycle \\
\hline BMX Apolo RR & Transgenic & Indeterminate & 5.5 & Super-early \\
\hline BMX Força RR & Transgenic & Indeterminate & 6.2 & Early \\
\hline BMX Magna RR & Transgenic & Indeterminate & 6.2 & Early \\
\hline BMX Potência RR & Transgenic & Indeterminate & 6.7 & Semi-early \\
\hline BMX Turbo RR & Transgenic & Indeterminate & 5.8 & Super-early \\
\hline BRS 133 & Conventional & Determinate & 7.3 & Late \\
\hline BRS 232 & Conventional & Determinate & 6.9 & Late \\
\hline BRS 245RR & Transgenic & Determinate & 7.2 & Late \\
\hline BRS 284 & Conventional & Indeterminate & 6.9 & Late \\
\hline BRS 294RR & Transgenic & Determinate & 6.3 & Early \\
\hline BRS 295RR & Transgenic & Determinate & 6.5 & Early \\
\hline BRS 316RR & Transgenic & Determinate & 6.5 & Early \\
\hline BRS 317 & Conventional & Determinate & 6.6 & Semi-early \\
\hline BRS 359RR & Transgenic & Indeterminate & 6.5 & Early \\
\hline BRS 360RR & Transgenic & Indeterminate & 6.5 & Early \\
\hline FTS Campo Mourão RR & Transgenic & Determinate & 6.5 & Early \\
\hline NA 5909RR & Transgenic & Indeterminate & 6.7 & Semi-early \\
\hline NA $6262 R R$ & Transgenic & Indeterminate & 6.4 & Early \\
\hline NEX 457 IPRO & Transgenic & Indeterminate & 5.8 & Super-early \\
\hline TMG 1066RR & Transgenic & Determinate & 6.6 & Semi-early \\
\hline TMG 1067RR & Transgenic & Determinate & 6.7 & Semi-early \\
\hline TMG 7161RR & Transgenic & Indeterminate & 6.1 & Early \\
\hline TMG 7262RR & Transgenic & Indeterminate & 6.2 & Early \\
\hline Vmax RR & Transgenic & Indeterminate & 6.4 & Early \\
\hline
\end{tabular}


(Embrapa 1997): $\mathrm{pH}$, calcium chloride $\left(\mathrm{CaCl}_{2} 0.1 \mathrm{~mol} \mathrm{~L}^{-1}\right)=4.4$, soil organic matter (SOMWalkley-Black $)=12.3 \mathrm{~g} \mathrm{~kg}^{-1}$, phosphorus- $\mathrm{P}($ Mehlich 1 extractant $)=3.0 \mathrm{mg} \mathrm{kg}{ }^{-1}$, potassium- $\mathrm{K}^{+}$ $\left(\right.$ Mehlich 1) $=0.1 \mathrm{cmol}_{\mathrm{c}} \mathrm{kg}^{-1}, \mathrm{Ca}^{2+}$ (potassium chloride $(\mathrm{KCl}) 1.0 \mathrm{~mol} \mathrm{~L}{ }^{-1}$ ) $=0.1 \mathrm{cmol}_{\mathrm{c}} \mathrm{kg}^{-1}$, magnesium- $\mathrm{Mg}^{2+}\left(\mathrm{KCl} 1.0 \mathrm{~mol} \mathrm{~L} \mathrm{~L}^{-1}\right)=0.3 \mathrm{cmol}_{\mathrm{c}} \mathrm{kg}^{-1}$, aluminum- $\mathrm{Al}^{3+}$ ( $\mathrm{KCl}$ extractant $\left.1.0 \mathrm{~mol} \mathrm{~L}{ }^{-1}\right)=0.3 \mathrm{cmol}_{\mathrm{c}} \mathrm{kg}^{-1}$, potential acidity-hydrogen $\left(\mathrm{H}^{+}\right)+\mathrm{Al}^{3+}=3.1 \mathrm{cmol}_{\mathrm{c}} \mathrm{kg}^{-1}$, sulfur-S$\mathrm{SO}_{4}{ }^{-}\left(\mathrm{CaCl}_{2} 0.01 \mathrm{~mol} \mathrm{~L}^{-1}\right)=6.0 \mathrm{mg} \mathrm{kg}{ }^{-1}$, cation exchange capacity-CEC $\left(\sum \mathrm{K}^{+}, \mathrm{Ca}^{2+}, \mathrm{Mg}^{2+}\right.$, $\left.\mathrm{H}^{+}+\mathrm{Al}^{3+}\right)=3.6 \mathrm{cmol}_{\mathrm{c}} \mathrm{kg}^{-1}$, base saturation $-\mathrm{V}=6.0 \%, \mathrm{~B}$ (hot water) $=0.18 \mathrm{mg} \mathrm{kg} \mathrm{kg}^{-1}, \mathrm{Cu}$ $\left(\right.$ Mehlich 1) $=0.5 \mathrm{mg} \mathrm{kg}^{-1}$, Fe (Mehlich 1) $=73.0 \mathrm{mg} \mathrm{kg}^{-1}, \mathrm{Mn}\left(\right.$ Mehlich 1) $=18.4 \mathrm{mg} \mathrm{kg}^{-1}, \mathrm{Zn}$ $($ Mehlich 1$)=0.4 \mathrm{mg} \mathrm{kg}^{-1}$, clay $=86 \mathrm{~g} \mathrm{~kg}^{-1}$, and sand $=870 \mathrm{~g} \mathrm{~kg}^{-1}$.

The experiment followed a completely randomized design with three replicates. Two months before planting, soil acidity was corrected with the use of dolomite lime $(27.78 \%$ of calcium oxide $(\mathrm{CaO}), 19.62 \%$ of magnesium oxide $(\mathrm{MgO})$, and $85.5 \%$ neutralizing power) to increase base saturation $\left[\left(\sum \mathrm{K}^{+}, \mathrm{Ca}^{2+}, \mathrm{Mg}^{2+}\right) /\left(\sum \mathrm{K}^{+}, \mathrm{Ca}^{2+}, \mathrm{Mg}^{2+}, \mathrm{H}^{+}+\mathrm{Al}^{3+}\right) \times 100\right]$ to $60 \%$. Fertilizations with $\mathrm{P}, \mathrm{K}, \mathrm{S}, \mathrm{B}$, cobalt $(\mathrm{Co}), \mathrm{Cu}, \mathrm{Fe}$, molybdenum (Mo), $\mathrm{Mn}$, nickel $(\mathrm{Ni})$, and $\mathrm{Zn}$ were performed according to Moreira, Fageria, and Garcia Y Garcia (2011), adapted from Allen, Terman, and Clements (1976) for experiments conducted in greenhouse conditions: $50 \mathrm{mg} \mathrm{kg}^{-1}$ of $\mathrm{K}(\mathrm{KCl}) ; 150 \mathrm{mg} \mathrm{kg} \mathrm{kg}^{-1} \mathrm{P}$ (monoammonium phosphate (MAP)), $0.5 \mathrm{mg} \mathrm{kg}{ }^{-1}$ of B (boric acid $\left(\mathrm{H}_{3} \mathrm{BO}_{3}\right)$ ); $1.5 \mathrm{mg} \mathrm{kg}^{-1}$ of $\mathrm{Cu}$ (copper sulfate heptahydrate $\left(\mathrm{CuSO}_{4} \times 7 \mathrm{H}_{2} \mathrm{O}\right)$ ); $0.1 \mathrm{mg} \mathrm{kg}^{-1}$ of Mo (Sodium molybdate $\times$ hydrogen peroxide $\left(\mathrm{Na}_{2} \mathrm{Mo}_{4} \times 2 \mathrm{H}_{2} \mathrm{O}\right)$ ); $2.5 \mathrm{mg} \mathrm{kg}^{-1}$ of $\mathrm{Fe}$ (iron sulfate $\left(\mathrm{FeSO}_{4}\right) \times 2 \mathrm{H}_{2} \mathrm{O}$ ); $0.01 \mathrm{mg} \mathrm{kg}^{-1}$ of Co (cobalt chloride $\left(\mathrm{CoCl}_{2}\right) ; 0,01 \mathrm{mg} \mathrm{kg}{ }^{-1}$ of $\mathrm{Ni}$ (nickel sulfate $\times \mathrm{NiSO}_{4} \times 6 \mathrm{H}_{2} \mathrm{O}$ ); $5.0 \mathrm{mg} \mathrm{kg}^{-1}$ of Mn $\left(\mathrm{MnSO}_{4} \times 3 \mathrm{H}_{2} \mathrm{O}\right), 5.0 \mathrm{mg} \mathrm{kg}$ of $\mathrm{Zn}\left(\mathrm{ZnSO}_{4} \times 6 \mathrm{H}_{2} \mathrm{O}\right)$ and $50 \mathrm{mg} \mathrm{kg}^{-1}$ of S (potassium sulfate $\left(\mathrm{K}_{2} \mathrm{SO}_{4}\right)$ ). Thirty days after planting, topdressing was done with $100 \mathrm{mg} \mathrm{kg}^{-1}$ of $\mathrm{K}\left(\mathrm{K}_{2} \mathrm{SO}_{4}\right)$.

The plants were watered daily with deionized water to compensate for the losses by evapotranspiration and to keep the total porosity of soil at 70\% by volume (Cassel and Nielsen 1986). Ten seeds of each variety were treated with turf containing Bradyrhizobium elkanii [SEMIA 587 and SEMIA $5019\left(4.0 \times 10^{9}\right.$ viable cells $\mathrm{g}^{-1}$ )] and sown in the pots and 10 days later thinning was performed leaving two plants per pot.

At R2 growth stage (Fehr et al. 1971), SPAD values were measured on the leaves (fully expanded 3rd and 4th trifoliate leaves from the apex), with the values converted into chlorophyll content units $\left(\mathrm{mg} \mathrm{cm}^{-2}\right)$ by the equation $\hat{y}=16.033+(7.5774 \times \mathrm{SPAD})($ Fritschi and Ray 2007) and net photosynthesis rate- $\mathrm{A}(\mu \mathrm{mol}$ carbon dioxide $\left(\mathrm{CO}_{2}\right) \mathrm{m}^{-2} \mathrm{~s}^{-1}$ ) was determined on the same leaves with a portable photosynthesis analyzer (LI-6400XT; LI-COR ${ }^{\oplus}$ ). Senescent leaves were collected during the entire soybean cycle and at the end of the cycle they were dried in oven for determination of the shoot dry weight yield (SDWY, Eleaves, pods seeds, and stems). After harvest and weighing, the seeds were ground for determination of the total N, P, K, Ca, $\mathrm{Mg}, \mathrm{S}, \mathrm{B}, \mathrm{Cu}, \mathrm{Fe}, \mathrm{Mn}$, and $\mathrm{Zn}$ concentration and analyzed according to the methods described by Malavolta, Vitti, and Oliveira (1997).

Based on the seed yield for the different varieties and on the nutrients concentration, the following variables were calculated:

Seed harvest index $(\mathrm{SHI})=\frac{\text { Seed yield }}{(\text { Seed yield }+ \text { SDW yield })}$, according to Fageria, Barbosa Filho, and Moreira (2008), and nutrient-use efficiency (NUE) $=\frac{\text { Seed yield }{ }^{2}}{\text { Nutrients concentration in seed }}$, equation adapted from Siddiqi, Chyan, and Freiji (1994).

The data were subjected to analysis of variance (ANOVA) and F-test, and Scott-Knott grouping test at the $5 \%$ probability level was used for the means of the 24 varieties for each assessed variable. Because of the diversity of treatments, orthogonal contrasts $(p \leq 0.05)$ were used in the comparisons of means of the different genetic characteristics of the varieties.

\section{Results and discussion}

\section{Yield and physiological components}

The number of pods (NP), seed yield (SY), SDWY, and the SHI were significantly affected by the soybean varieties (Table 2). The NP ranged from 34 in variety BRS 316RR to 101 in BRS 295RR, with 
an average value of 54 pods per plant. Because of the genetic characteristics of each variety, which had different amounts of seeds per pod, the NP per plant showed positive correlation only with SDWY $(\hat{y}=31.624+0.717 x, r=0.67, p \leq 0.05)$, though not converted into SY $(\hat{y}=20.8)$. Conflicting results were obtained by Fageria et al. (2012b) for common bean (Phaseolus vulgaris), who reported a significant and positive correlation with SY despite the high variability in the number of pods per plant. In the present experiment, the highest SY was observed for variety BRS $232(29 \mathrm{~g} / \mathrm{pot})$ and the lowest SY for BMX Força RR (16.1 g/pot), with the average of the varieties being $22.1 \mathrm{~g} / \mathrm{pot}$ (Table 2). Regarding the SHI, the range of variation was $0.20-0.45$, with an average value of 0.32 , with varieties BRS 284, TMG 1067RR, and BMX Magna RR obtaining the highest values and varieties BRS 133 and BMX Força RR, the lowest values (Table 2).

In the comparison of the varieties, 12.5\% had SHI higher than 0.43 (BMX Magma, BRS 284 and TMG 1067RR), 29\% between 0.35 and 0.42 (BRS 232, BRS 317, FTS Campo Mourão RR, BMX Turbo RR, NA 6262RR, TMG 7161RR and TMG 7262RR), 50\% between 0.24 and 0.34 (BRS 294RR, BRS 295RR, TMG 1066RR, NEX 457 IPRO, BRS 316RR, BMX Apolo RR, BMX Potência RR, BRS 359RR, BRS 360RR, BRS 245RR, VMAX RR, and NA 5909RR. Corroborating Araújo and Teixeira (2012), in the process of selection of varieties, the SHI can well reflect the efficiency in the allocation of plant biomass to the seeds of a given variety and/or species. Sinclair (1998) and Fageria, Barbosa Filho, and Moreira (2008) also report that this variable can reliably indicate the partitioning of photosynthates between the seeds and the vegetative part of the plant.

The net photosynthesis rate $(\mathrm{A})$ and the chlorophyll content $(\mathrm{Cl})$ varied significantly between the soybean varieties, with a significant correlation between these two variables $[\mathrm{A}=146.450+6.581(\mathrm{Cl})$, $r=0.80, p \leq 0.05]$. The highest values reported for photosynthesis rate were obtained in the varieties BRS 316RR $\left(25.821 \mathrm{mmol} \mathrm{CO}_{2} \mathrm{~m}^{-2} \mathrm{~s}^{-1}\right)$ and BRS $317\left(25.889 \mathrm{mmol} \mathrm{CO}_{2} \mathrm{~m}^{-2} \mathrm{~s}^{-1}\right)$ and the lowest values in

Table 2. Yield and physiological components of 24 soybean varieties.

\begin{tabular}{|c|c|c|c|c|c|c|}
\hline Varieties & Pods & SY & SDWY & Photosynthesis & Chlorophyll & SHI \\
\hline & (n) & (g/pot) & (g/pot) & $\left(\mu \mathrm{mol} \mathrm{CO} \mathrm{CO}_{2} \mathrm{~m}^{-2} \mathrm{~s}^{-1}\right)$ & $\left(\mathrm{mg} \mathrm{m}^{-2}\right)$ & \\
\hline BRS 133 & $75 b$ & $24.7 c$ & $121.6 a$ & $22.151 b$ & $267.35 b$ & $0.20 d$ \\
\hline BRS 232 & $58 c$ & $29.0 a$ & $75.5 c$ & $20.317 b$ & $277.94 b$ & $0.38 b$ \\
\hline BRS 317 & $44 c$ & $24.2 b$ & $64.9 c$ & $25.889 a$ & 339.01a & $0.37 b$ \\
\hline BRS 284 & $49 c$ & $28.1 \mathrm{~b}$ & $64.7 c$ & $19.405 b$ & $258.45 c$ & $0.43 a$ \\
\hline BRS 294RR & $75 b$ & $17.9 \mathrm{c}$ & $75.4 c$ & $12.707 c$ & $247.97 c$ & $0.24 c$ \\
\hline BRS 295RR & $101 a$ & $20.6 c$ & $105.7 \mathrm{~b}$ & $11.574 c$ & $210.84 d$ & $0.27 c$ \\
\hline TMG 1066RR & $78 b$ & $19.9 c$ & $69.2 c$ & $15.767 c$ & $223.84 c$ & $0.29 c$ \\
\hline BRS 245RR & $65 b$ & $27.5 b$ & $113.7 \mathrm{a}$ & $14.888 \mathrm{c}$ & $200.50 d$ & $0.24 c$ \\
\hline TMG 1067RR & $47 c$ & $24.4 b$ & $56.5 c$ & $15.151 c$ & $243.44 c$ & $0.43 a$ \\
\hline BRS 316RR & $34 c$ & $18.2 c$ & $57.6 \mathrm{~b}$ & $25.821 a$ & $294.77 b$ & $0.32 c$ \\
\hline FTS Campo Mourão RR & $46 c$ & $24.4 b$ & $65.1 b$ & $15.730 \mathrm{c}$ & $257.05 c$ & $0.37 b$ \\
\hline BMX Apolo & $39 c$ & $19.2 c$ & $57.4 b$ & $18.355 b$ & $300.88 b$ & $0.33 c$ \\
\hline BMX Força & $53 c$ & $16.1 \mathrm{c}$ & $78.2 b$ & $15.584 c$ & $243.73 c$ & $0.21 d$ \\
\hline BMX Potência & $49 c$ & $21.2 \mathrm{c}$ & $72.7 b$ & $16.185 c$ & $287.49 b$ & $0.29 c$ \\
\hline BMX Turbo & $53 c$ & $22.9 c$ & $64.8 \mathrm{~b}$ & $13.216 c$ & $237.61 c$ & $0.35 b$ \\
\hline BRS 359RR & $71 b$ & $21.1 \mathrm{c}$ & $73.6 \mathrm{~b}$ & $14.258 c$ & $233.13 c$ & $0.29 c$ \\
\hline BRS 360RR & $42 c$ & $18.5 c$ & $66.4 b$ & $16.009 c$ & $262.87 c$ & $0.28 c$ \\
\hline NA 5909RR & $47 c$ & $20.1 c$ & $70.9 b$ & $12.923 c$ & $233.82 \mathrm{c}$ & $0.28 c$ \\
\hline NA $6262 R R$ & $43 c$ & $19.1 c$ & $54.4 c$ & $14.154 c$ & $259.71 c$ & $0.35 b$ \\
\hline NEX 457 IPRO & $69 \mathrm{~b}$ & $19.3 c$ & $67.7 \mathrm{~b}$ & $12.291 \mathrm{C}$ & $219.93 d$ & $0.28 c$ \\
\hline TMG 7161RR & $51 c$ & $21.2 c$ & $59.7 b$ & $15.186 c$ & $251.19 c$ & $0.36 b$ \\
\hline TMG 7262RR & $42 c$ & $20.4 c$ & $59.0 \mathrm{~b}$ & $21.148 b$ & $273.22 b$ & $0.35 b$ \\
\hline VMAX RR & $78 \mathrm{~b}$ & $21.0 c$ & $73.3 b$ & $13.656 c$ & $216.58 d$ & $0.29 c$ \\
\hline BMX Magna RR & $47 c$ & $28.2 b$ & $62.4 b$ & $19.296 b$ & $296.60 b$ & $0.45 a$ \\
\hline Average & 56 & 22.0 & 72.1 & 16.736 & 255.75 & 0.32 \\
\hline Minimum & 34 & 16.1 & 54.4 & 11.574 & 200.50 & 0.20 \\
\hline Maximum & 101 & 29.0 & 121.6 & 25.889 & 339.01 & 0.45 \\
\hline CV\% & 17.18 & 9.78 & 12.06 & 12.98 & 7.97 & 14.21 \\
\hline
\end{tabular}

Means followed by different letters in the same column differ by Scott-Knott test at 5\% probability. SHI, seed harvest index; SY, seed yield; SDWY, shoot dry weight yield. 
BRS 295RR (11,574 mmol CO $\left.2 \mathrm{~m}^{-2} \mathrm{~s}^{-1}\right)$ and NEX 457 IPRO (12.291 $\mathrm{mmol} \mathrm{CO}_{2} \mathrm{~m}^{-2} \mathrm{~s}^{-1}$ ), respectively (Table 2). Under ideal or adverse environmental conditions, genetic variation may lead to differences in the use efficiency of solar radiation by plants and in the partition of photoassimilates, impacting growth and yield in the comparison with another species or variety (Fageria 1998; Taiz and Zaiger 2010). Bottrill, Possingham, and Kriedemann (1970) found that nutritional imbalance alters the assimilation of carbon (C) in the plants, negatively interfering with photosynthesis and chlorophyll content.

\section{Nutrient concentration and uptake in the seeds}

The concentrations (nutrient content per unit dry weight) and uptake (nutrient concentration in seed $\times$ seed weight per pot) are shown in Tables 3 and 4 . Differences were observed between the varieties, with BMX Apolo RR showing the highest number of nutrients with the highest concentrations ( $\mathrm{P}, \mathrm{Ca}, \mathrm{Mg}, \mathrm{B}$, and $\mathrm{Fe}$ ), while the lowest values were obtained by BRS 232 (Zn), BRS $284(\mathrm{P})$, BRS 245RR (S), NEX 457 IPRO (P), and BMX Força RR (P). Regarding uptake, the highest nutrients number was observed in BRS 232 and the lowest in BRS 294RR and BMX Força RR. N and K concentrations ranged from 49.47 to $69.70 \mathrm{~g} \mathrm{~kg}^{-1}$ and from 15.39 to $20.97 \mathrm{~g} \mathrm{~kg}^{-1}$ and the average concentration was 55.99 and $17.58 \mathrm{~g} \mathrm{~kg}^{-1}$, respectively. Among the varieties. BRS 317 and BRS 316RR showed the highest $\mathrm{N}$ and $\mathrm{K}$ concentrations in the seeds. Regarding biofortification, in the animal body $\mathrm{K}$ acts mainly in the distribution of fluids inside and outside the cell and also participates in the regulation of acid-base balance, being involved in cell growth, protein synthesis, among other metabolites (Navarro and Vaquero 2003). As for $\mathrm{N}$, it is part of amino acids (AAs) composition, and, consequently, of proteins that have several functions such as deoxyribonucleic acid (DNA) replication, component of the plasma membrane, and formation of cytoskeleton and chromosomes (Caballero, Trugo, and Finglas 2003).

The varieties also differed significantly in the $\mathrm{P}, \mathrm{Ca}, \mathrm{Mg}$, and S concentration (Table 3), with variation of $63.1 \%$ in P (BRS 284 and BRS 359RR), 190.8\% in Ca (BRS 133 and BMX Apolo RR), $50.5 \%$ in Mg (BMX Magna RR and BMX Apolo RR), and 71.3\% in S (BMX Magna RR and TMG 7262RR). Similarly, uptake was also influenced by the varieties $(p \leq 0.05)$. P ranged from 0.09 to $0.15 \mathrm{mg} / \mathrm{pot}$, Ca ranged from 0.03 to $0.09 \mathrm{mg} /$ pot, $\mathrm{Mg}$ from 0.04 to $0.07 \mathrm{mg} /$ pot, and S from 0.04 to $0.08 \mathrm{mg} /$ pot (Table 4). On average, the concentration and uptake of macronutrients in soybean seeds was $\mathrm{N}>\mathrm{K}>\mathrm{P}>\mathrm{Ca} \sim \mathrm{S}>\mathrm{Mg}$, a sequence different from the one obtained by Fageria et al. (2013) in a Xanthic Ferralsol with $403 \mathrm{~g} \mathrm{~kg}^{-1}$ of clay. Inside the body, $\mathrm{P}$ acts in the formation of bones and teeth, as a component for molecule regulation and in the composition of ATP (adenosine triphosphate), especially in the mitochondria, among other functions (Anderson 2003). The Ca element is mainly present in the structural part, such as bones and teeth, and prolonged deficiency of the nutrient leads to the development of diseases such as osteoporosis (L'Abbé 2003). It should be stressed that the selection of varieties with high $\mathrm{Ca}$ concentrations in soybean water soluble extract (WSE) can be a good alternative to bovine milk, since $75 \%$ of the population have different degrees of lactose intolerance (Casé et al. 2005). Regarding Mg, this nutrient performs several physiological and biochemical functions in humans and animals, and its higher concentration inside the cell is in the mitochondria, and is essential cofactor for carboxylase and coenzyme Q (Griffin 2003), while the $S$ in the body is part of the structures of some essential AAs (cysteine, methionine, and taurine), forming the disulfide bridge between polypeptides, a very important bond for the formation of the spatial structures of proteins. (Taiz and Zeiger 2010).

The concentration and uptake of $\mathrm{B}, \mathrm{Cu}, \mathrm{Fe}, \mathrm{Mn}$, and $\mathrm{Zn}$ in the seeds were also significantly influenced by soybean varieties (Tables 3 and 4). The varieties BMX Apolo RR and TMG 7262RR showed the highest concentrations of B (34.38 and $36.23 \mathrm{mg} \mathrm{kg}{ }^{-1}$ ) and BMX Magna RR (10.06 mg kg-1), being $118.3 \%, 130.0 \%$, and $438.0 \%$ higher than those of FTS Campo Mourão RR (B) and BMX Força RR (Cu), respectively. In the $\mathrm{B}$ and $\mathrm{Cu}$ uptake by the seeds (Table 4 ), the highest amount of $\mathrm{B}$ was reported in TMG 7262RR $(0.74 \mu \mathrm{g} / \mathrm{pot})$ and $\mathrm{Cu}$ in BMX Magna RR $(0.28 \mu \mathrm{g} / \mathrm{pot})$ and the lowest amounts in BMX Força RR (0.32 and $0.03 \mu \mathrm{g} / \mathrm{pot})$. According to Hunt (2003), in the human body, B modifies and possibly 


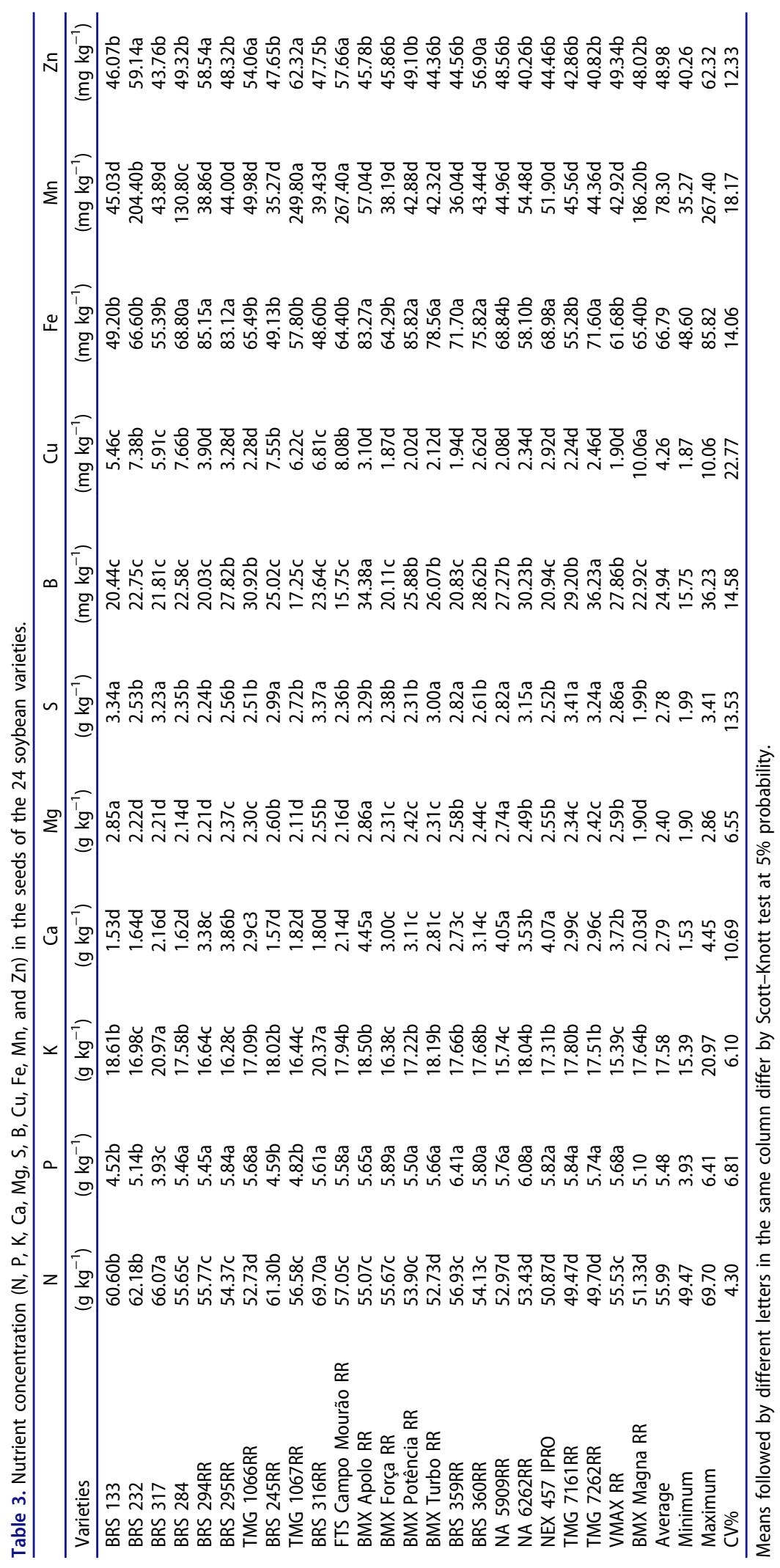


Table 4. Nutrient uptake ( $N, P, K, C a, M g, S, B, C u, F e, M n$, and $\mathrm{Zn}$ ) in seeds of the 24 soybean varieties.

\begin{tabular}{|c|c|c|c|c|c|c|c|c|c|c|c|}
\hline & $\mathrm{N}$ & $\mathrm{P}$ & $\mathrm{K}$ & $\mathrm{Ca}$ & $\mathrm{Mg}$ & $S$ & B & $\mathrm{Cu}$ & $\mathrm{Fe}$ & $\mathrm{Mn}$ & $\mathrm{Zn}$ \\
\hline Varieties & $\begin{array}{l}\text { (mg/ } \\
\text { pot) }\end{array}$ & $\begin{array}{l}\text { (mg/ } \\
\text { pot) }\end{array}$ & $\begin{array}{l}\text { (mg/ } \\
\text { pot) }\end{array}$ & $\begin{array}{l}\text { (mg/ } \\
\text { pot) }\end{array}$ & $\begin{array}{l}\text { (mg/ } \\
\text { pot) }\end{array}$ & $\begin{array}{l}\text { (mg/ } \\
\text { pot) }\end{array}$ & $\begin{array}{l}(\mu \mathrm{g} / \\
\mathrm{pot})\end{array}$ & $\begin{array}{l}(\mu \mathrm{g} / \\
\mathrm{pot})\end{array}$ & $\begin{array}{l}(\mu \mathrm{g} / \\
\mathrm{pot})\end{array}$ & $\begin{array}{l}(\mu \mathrm{g} / \\
\mathrm{pot})\end{array}$ & $\begin{array}{l}(\mu \mathrm{g} / \\
\mathrm{pot})\end{array}$ \\
\hline BRS 133 & $1.50 \mathrm{~b}$ & $0.11 b$ & $0.46 \mathrm{~b}$ & $0.04 c$ & $0.07 a$ & $0.08 a$ & $0.51 \mathrm{a}$ & $0.14 c$ & $1.22 \mathrm{c}$ & $1.11 \mathrm{~d}$ & $1.14 b$ \\
\hline BRS 232 & $1.81 \mathrm{a}$ & $0.15 a$ & $0.49 a$ & $0.05 c$ & $0.06 \mathrm{~b}$ & $0.07 a$ & $0.66 a$ & $0.21 b$ & $1.93 a$ & $5.94 a$ & $1.72 \mathrm{a}$ \\
\hline BRS 317 & $1.60 \mathrm{a}$ & $0.09 \mathrm{~b}$ & $0.51 a$ & $0.05 c$ & $0.05 c$ & $0.08 a$ & $0.53 a$ & $0.14 c$ & $1.34 c$ & $1.06 \mathrm{~d}$ & $1.06 \mathrm{~b}$ \\
\hline BRS 284 & $1.57 a$ & $0.15 \mathrm{a}$ & $0.49 a$ & $0.05 c$ & $0.06 \mathrm{~b}$ & $0.07 a$ & $0.63 a$ & $0.22 \mathrm{~b}$ & $1.93 a$ & $3.68 c$ & $1.39 a$ \\
\hline BRS 294RR & $1.00 c$ & $0.10 \mathrm{~b}$ & $0.30 c$ & $0.06 \mathrm{~b}$ & $0.04 d$ & $0.04 b$ & $0.36 \mathrm{~b}$ & $0.07 c$ & $1.52 \mathrm{~b}$ & $0.70 \mathrm{~d}$ & $1.05 b$ \\
\hline BRS 295RR & $1.12 \mathrm{c}$ & $0.12 b$ & $0.33 c$ & $0.08 a$ & $0.05 c$ & $0.05 b$ & $0.57 a$ & $0.07 c$ & $1.71 \mathrm{~b}$ & $0.90 \mathrm{~d}$ & $0.99 b$ \\
\hline TMG 1066RR & $1.05 c$ & $0.11 \mathrm{~b}$ & $0.34 c$ & $0.06 \mathrm{~b}$ & $0.05 c$ & $0.05 b$ & $0.62 \mathrm{a}$ & $0.05 c$ & $1.31 \mathrm{c}$ & $1.00 \mathrm{~d}$ & $1.08 \mathrm{~b}$ \\
\hline BRS 245RR & $1.68 \mathrm{a}$ & $0.13 a$ & $0.50 \mathrm{a}$ & $0.04 c$ & $0.07 a$ & $0.08 a$ & $0.69 a$ & $0.21 b$ & $1.35 c$ & $0.97 d$ & $1.31 \mathrm{a}$ \\
\hline TMG 1067RR & $1.38 \mathrm{~b}$ & $0.12 b$ & $0.40 c$ & $0.04 c$ & $0.05 c$ & $0.07 a$ & $0.42 \mathrm{~b}$ & $0.15 c$ & $1.41 \mathrm{c}$ & $6.10 a$ & $1.52 \mathrm{a}$ \\
\hline BRS 316RR & $1.27 \mathrm{c}$ & $0.10 \mathrm{~b}$ & $0.37 c$ & $0.03 c$ & $0.05 c$ & $0.06 a$ & $0.43 b$ & $0.12 c$ & $0.88 d$ & $0.72 d$ & $0.87 \mathrm{~b}$ \\
\hline FTS Campo Mourão RR & $1.39 \mathrm{~b}$ & $0.14 a$ & $0.44 b$ & $0.05 c$ & $0.05 c$ & $0.06 a$ & $0.38 b$ & $0.20 \mathrm{~b}$ & $1.57 \mathrm{~b}$ & $6.52 a$ & $1.40 \mathrm{a}$ \\
\hline BMX Apolo RR & $1.06 \mathrm{c}$ & $0.11 \mathrm{~b}$ & $0.35 c$ & $0.09 a$ & $0.05 c$ & $0.06 a$ & $0.66 a$ & $0.06 c$ & $1.60 \mathrm{~b}$ & $1.09 \mathrm{~d}$ & $0.88 \mathrm{~b}$ \\
\hline BMX Força RR & $0.90 \mathrm{c}$ & $0.09 b$ & $0.26 c$ & $0.05 c$ & $0.04 d$ & $0.04 b$ & $0.32 \mathrm{~b}$ & $0.03 c$ & $1.04 d$ & $0.62 d$ & $0.74 b$ \\
\hline BMX Potência RR & $1.14 c$ & $0.12 b$ & $0.37 c$ & $0.07 b$ & $0.05 c$ & $0.05 b$ & $0.55 a$ & $0.04 c$ & $1.82 a$ & $0.91 d$ & $1.04 b$ \\
\hline BMX Turbo RR & $1.21 \mathrm{c}$ & $0.13 a$ & $0.42 b$ & $0.06 \mathrm{~b}$ & $0.05 c$ & $0.07 a$ & $0.60 \mathrm{a}$ & $0.05 c$ & $1.80 a$ & $0.97 d$ & $1.01 \mathrm{~b}$ \\
\hline BRS 359RR & $1.20 \mathrm{c}$ & $0.14 a$ & $0.37 c$ & $0.06 \mathrm{~b}$ & $0.05 c$ & $0.06 a$ & $0.44 b$ & $0.04 c$ & $1.52 \mathrm{~b}$ & $0.76 \mathrm{~d}$ & $0.94 b$ \\
\hline BRS 360RR & $1.00 \mathrm{c}$ & $0.11 b$ & $0.33 c$ & $0.06 \mathrm{~b}$ & $0.05 c$ & $0.05 b$ & $0.53 a$ & $0.05 c$ & $1.40 c$ & $0.80 \mathrm{~d}$ & $1.05 b$ \\
\hline NA 5909RR & $1.06 c$ & $0.12 b$ & $0.32 c$ & $0.08 a$ & $0.06 \mathrm{~b}$ & $0.06 a$ & $0.55 a$ & $0.04 c$ & $1.38 \mathrm{c}$ & $0.90 \mathrm{~d}$ & $0.98 b$ \\
\hline NA $6262 R R$ & $1.02 \mathrm{C}$ & $0.12 b$ & $0.34 c$ & $0.07 b$ & $0.05 c$ & $0.06 a$ & $0.58 a$ & $0.04 c$ & $1.11 \mathrm{~d}$ & $1.04 d$ & $0.77 \mathrm{~b}$ \\
\hline NEX 457 IPRO & $0.98 c$ & $0.11 \mathrm{~b}$ & $0.33 c$ & $0.08 a$ & $0.05 c$ & $0.05 b$ & $0.40 \mathrm{~b}$ & $0.06 c$ & $1.33 c$ & $1.00 \mathrm{~d}$ & $0.86 \mathrm{~b}$ \\
\hline TMG 7161RR & $1.05 c$ & $0.12 b$ & $0.38 c$ & $0.06 \mathrm{~b}$ & $0.05 c$ & $0.07 a$ & $0.62 \mathrm{a}$ & $0.05 c$ & $1.17 \mathrm{~d}$ & $0.97 d$ & $0.91 b$ \\
\hline TMG 7262RR & $1.01 \mathrm{c}$ & $0.12 \mathrm{~b}$ & $0.36 c$ & $0.06 \mathrm{~b}$ & $0.05 c$ & $0.07 a$ & $0.74 a$ & $0.05 c$ & $1.46 \mathrm{c}$ & $0.90 \mathrm{~d}$ & $0.83 b$ \\
\hline VMAX RR & $1.17 c$ & $0.12 b$ & $0.32 \mathrm{c}$ & $0.08 a$ & $0.05 c$ & $0.06 a$ & $0.59 a$ & $0.04 c$ & $1.30 \mathrm{c}$ & $0.90 \mathrm{~d}$ & $1.04 b$ \\
\hline BMX Magna RR & $1.45 c$ & $0.14 a$ & $0.50 a$ & $0.06 \mathrm{~b}$ & $0.05 c$ & $0.06 a$ & $0.65 a$ & $0.28 a$ & $1.84 a$ & $5.25 b$ & $1.35 \mathrm{a}$ \\
\hline Average & 1.23 & 0.12 & 0.39 & 0.06 & 0.05 & 0.06 & 0.54 & 0.10 & 1.45 & 1.87 & 1.08 \\
\hline Minimum & 0.90 & 0.09 & 0.26 & 0.03 & 0.04 & 0.04 & 0.32 & 0.03 & 0.88 & 0.62 & 0.74 \\
\hline Maximum & 1.81 & 0.15 & 0.51 & 0.09 & 0.07 & 0.08 & 0.74 & 0.28 & 1.93 & 6.52 & 1.72 \\
\hline CV\% & 10.89 & 11.29 & 9.72 & 12.31 & 10.29 & 17.16 & 15.94 & 23.40 & 13.95 & 22.70 & 16.92 \\
\hline
\end{tabular}

Means followed by different letters in the same column differ by Scott-Knott test at $5 \%$ probability.

regulates the energy substrates and mineral metabolism, and acts in immune functions, while the metabolism and functions of $\mathrm{Cu}$ are related to the heart, blood vessels, nervous system, immune functions, hemoglobin formation, and bone health (Johnson 2003; Klevay 1980).

Among the 24 varieties (Tables 3 and 4), Fe concentration and uptake in the seeds increased by $76.6 \%$ from 48.60 (BRS 316RR) to $85.82 \mathrm{mg} \mathrm{kg}^{-1}$ (BMX Potência RR) and by $119.3 \%$ from 0.88 (BRS 316RR) to $1.93 \mu \mathrm{g} /$ pot (BRS 284); Mn by 658.1\% from 35.27 (BRS 245RR) to 267.40 (FTS Campo Mourão RR) and by 951.6\% from 0.62 (BMX Força RR) to $6.52 \mu \mathrm{g} /$ pot (FTS Campo Mourão RR); and Zn by $54.8 \%$ from 40.26 (NA 6262RR) to $62.32 \mathrm{mg} \mathrm{kg}^{-1}$ (TMG 1067RR) and by 132.4\% from 0.74 (BMX Força RR) to $1.72 \mu \mathrm{g} /$ pot (BRS 232). The mineral elements most commonly lacking in human diets are Fe and $\mathrm{Zn}$, which rank fifth and sixth, respectively, among the top 10 risk factors contributing to diseases, especially in developing countries. (Fageria et al. 2012b). The deficiency of Mn in humans causes, among other consequences, impact on growth and reproduction (Keen and Zidenberg-Cherr 2003). Fe plays a key role in the metabolic processes for transport and storage of oxygen $\left(\mathrm{O}_{2}\right)$, as well as in oxidative metabolism and cell growth (Lynch 2003), and the main symptom of deficiency of this mineral is iron deficiency anemia (Rios et al. 2009). Zn participates in the replication of all cells, transcription and DNA synthesis, messenger ribonucleic acid translation into proteins and stability of RNA structures. Zn deficiency causes delayed growth and immunological problems, neuropsychological manifestation, and increased morbidity (Ruz 2003).

The genetic differences detected in the varieties are important to define which types of soybean should be grown to obtain the highest concentration and uptake of a given nutrient by seeds (Table 5). The results indicated significant differences in the $\mathrm{N}, \mathrm{Cu}, \mathrm{Mn}$, and $\mathrm{Zn}$ concentrations in NGM varieties and in the concentrations of $\mathrm{Ca}$ in the GM variety, while regarding uptake, the introduction of the gene that confers glyphosate resistance affected N, K, Cu, Fe, Mn, and Zn uptake. Regarding soybean growth habit in NGM varieties, effects on nutrient concentrations in the seeds were observed only for $\mathrm{S}, \mathrm{Fe}$, and $\mathrm{Mn}$ 
concentrations; in the $\mathrm{GM}$ varieties for $\mathrm{Ca}, \mathrm{Cu}, \mathrm{Mn}$, and $\mathrm{Zn}$ concentrations; and on the average of NGM and $\mathrm{GM}$ varieties, for $\mathrm{Ca}, \mathrm{Cu}, \mathrm{Mn}$, and $\mathrm{Zn}$ concentrations. Regarding uptake, these effects were significant in $\mathrm{Cu}, \mathrm{Fe}$, and $\mathrm{Mn}$ concentrations in $\mathrm{NGM}$; in $\mathrm{N}, \mathrm{Cu}, \mathrm{Mn}$, and $\mathrm{Zn}$ concentrations in $\mathrm{GM}$; and in $\mathrm{N}, \mathrm{Cu}, \mathrm{Mn}$, and $\mathrm{Zn}$ concentrations on the average of NGM and GM varieties (Table 5). Fageria, Barbosa Filho, and Moreira (2008), Fageria, Moreira, and Coelho (2012a), and Rios et al. (2009) also reported the presence of genetic factors on the efficiency of nutrient uptake by seeds.

\section{Classification of varieties for nutrient-use efficiency}

Using the nutrient-use efficiency (NUE) in soybean seeds in the classification of varieties, significant differences were observed between these varieties, with BRS 284 (N, P, K, CA, Mg, and Zn), BRS 245RR (P, $\mathrm{K}, \mathrm{Ca}, \mathrm{Fe}, \mathrm{Mn}$, and $\mathrm{Zn}$ ), and BMX Magna RR (N, P, K, Mg, S, and $\mathrm{Zn}$ ) showing the highest NUE values, with six nutrients in the group with highest efficiency. The opposite was observed for BRS 294RR, BRS 316RR, BMX Apolo RR, BMX Força RR, BMX Potência RR, BRS 360RR, and NEX 457 IPRO, that had no nutrient in the group of highest efficiency and were classified, according to analysis by Scott-Knott (Scott and Knott 1974) in the groups of intermediate or low NUE (Table 6). Corroborating Welch and Graham (2002, 2004), Rios et al. (2009) and Fageria et al. (2012b), the identification of genetic differences between soybean varieties can be an important strategy for the biofortification of seeds of food crops (fresh or processed,) or indirectly as ingredients for animal feeds or similar products.

Table 5. Significance of F-contrast tests between the characteristics of cultivars and the means for the concentrations and uptake of nutrients in soybean seeds.

\begin{tabular}{|c|c|c|c|c|c|c|c|c|c|c|c|}
\hline Contrasts & $\mathrm{N}$ & $\mathrm{P}$ & $\mathrm{K}$ & $\mathrm{Ca}$ & $\mathrm{Mg}$ & $\mathrm{S}$ & B & $\mathrm{Cu}$ & $\mathrm{Fe}$ & $\mathrm{Mn}$ & $\mathrm{Zn}$ \\
\hline & \multicolumn{6}{|c|}{ Concentration, $\mathrm{g} \mathrm{kg}^{-1}$} & \multicolumn{5}{|c|}{ Concentration, $\mathrm{mg} \mathrm{kg}^{-1}$} \\
\hline Conventional (determinate + indeterminate)-a & 61.13 & 4.76 & 18.53 & 1.74 & 2.36 & 2.86 & 21.90 & 6.60 & 60.00 & 106.03 & 49.57 \\
\hline Transgenic (determinate + indeterminate) $-b$ & 54.96 & 5.62 & 17.39 & 3.00 & 2.41 & 2.76 & 25.55 & 3.79 & 68.15 & 72.75 & 48.86 \\
\hline $\mathrm{a}$ vs. $\mathrm{b}$ & * & ns & ns & * & Ns & ns & ns & * & ns & * & ns \\
\hline Determinate (transgenic + conventional) $-c$ & 59.64 & 5.12 & 17.93 & 2.28 & 2.36 & 2.78 & 22.54 & 5.69 & 62.49 & 101.81 & 52.53 \\
\hline Indeterminate (transgenic + conventional) $-d$ & 53.38 & 5.74 & 17.33 & 3.16 & 2.44 & 2.77 & 26.65 & 3.24 & 69.87 & 61.51 & 46.44 \\
\hline C vs. d & ns & ns & ns & * & ns & ns & ns & * & ns & * & * \\
\hline Conventional determinate-e & 62.95 & 4.53 & 18.85 & 1.78 & 2.43 & 3.03 & 21.67 & 6.25 & 57.06 & 97.78 & 49.66 \\
\hline Transgenic determinate-f & 58.21 & 5.37 & 17.54 & 2.50 & 2.33 & 2.68 & 22.92 & 5.45 & 64.81 & 103.53 & 53.76 \\
\hline e vs. f & ns & ns & ns & * & Ns & * & ns & Ns & ns & ns & * \\
\hline Conventional indeterminate $-\mathrm{g}$ & 62.95 & 4.53 & 18.85 & 1.78 & 2.43 & 3.03 & 21.67 & 6.25 & 57.06 & 97.78 & 49.66 \\
\hline Conventional determinate-e & 55.65 & 5.46 & 17.58 & 1.62 & 2.14 & 2.35 & 22.58 & 7.66 & 68.80 & 130.80 & 49.32 \\
\hline g vs. e & ns & ns & ns & ns & ns & $*$ & ns & ns & * & * & ns \\
\hline Determinate transgenic - $f$ & 58.21 & 5.37 & 17.54 & 2.50 & 2.33 & 2.68 & 22.92 & 5.45 & 64.81 & 103.53 & 53.76 \\
\hline Indeterminate transgenic-g & 53.21 & 5.76 & 17.31 & 3.28 & 2.46 & 2.80 & 26.96 & 2.90 & 69.95 & 56.18 & 46.22 \\
\hline \multirow{2}{*}{ f vs. $g$} & ns & ns & ns & * & ns & ns & ns & * & ns & * & * \\
\hline & \multicolumn{6}{|c|}{ Uptake, mg/pot } & \multicolumn{5}{|c|}{ Uptake, $\mu \mathrm{g} /$ pot } \\
\hline Conventional (determinate + indeterminate) $-a$ & 1.61 & 0.13 & 0.49 & 0.05 & 0.06 & 0.07 & 0.58 & 0.18 & 1.61 & 2.94 & 1.32 \\
\hline Transgenic (determinate +indeterminate) $-b$ & 1.16 & 0.12 & 0.37 & 0.06 & 0.05 & 0.06 & 0.53 & 0.08 & 1.42 & 1.65 & 1.03 \\
\hline a vs. $\mathrm{b}$ & * & ns & * & ns & ns & ns & ns & * & * & * & * \\
\hline Determinate (transgenic + conventional) $-c$ & 1.37 & 0.12 & 0.41 & 0.05 & 0.05 & 0.06 & 0.52 & 0.13 & 1.42 & 2.37 & 1.20 \\
\hline Indeterminate (transgenic + conventional) $-d$ & 1.13 & 0.12 & 0.37 & 0.06 & 0.05 & 0.06 & 0.56 & 0.07 & 1.47 & 1.41 & 0.99 \\
\hline c vs. d & * & ns & ns & ns & ns & ns & ns & * & ns & * & * \\
\hline Conventional determinate-e & 1.63 & 0.12 & 0.49 & 0.05 & 0.06 & 0.08 & 0.56 & 0.16 & 1.50 & 2.70 & 1.30 \\
\hline Transgenic determinate $-f$ & 1.25 & 0.11 & 0.38 & 0.05 & 0.05 & 0.06 & 0.50 & 0.12 & 1.38 & 2.22 & 1.16 \\
\hline e vs. $f$ & 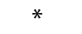 & ns & * & ns & ns & ns & ns & 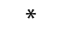 & ns & ns & * \\
\hline Conventional indeterminate- $-\mathrm{g}$ & 1.63 & 0.12 & 0.49 & 0.05 & 0.06 & 0.08 & 0.56 & 0.16 & 1.50 & 2.70 & 1.30 \\
\hline Conventional determinate-e & 1.57 & 0.15 & 0.49 & 0.05 & 0.06 & 0.07 & 0.64 & 0.21 & 1.93 & 3.64 & 1.39 \\
\hline g vs. e & ns & ns & ns & ns & ns & ns & ns & * & * & * & ns \\
\hline Determinate transgenic $-f$ & 1.25 & 0.11 & 0.38 & 0.05 & 0.05 & 0.06 & 0.50 & 0.12 & 1.38 & 2.22 & 1.16 \\
\hline Indeterminate transgenic $-\mathrm{g}$ & 1.10 & 0.12 & 0.36 & 0.07 & 0.05 & 0.06 & 0.55 & 0.06 & 1.44 & 1.24 & 0.95 \\
\hline h vs. $g$ & * & ns & ns & ns & ns & ns & ns & * & ns & $*$ & * \\
\hline
\end{tabular}

*Significant; ${ }^{\text {ns }}$ Non significant at $5 \%$ probability. 


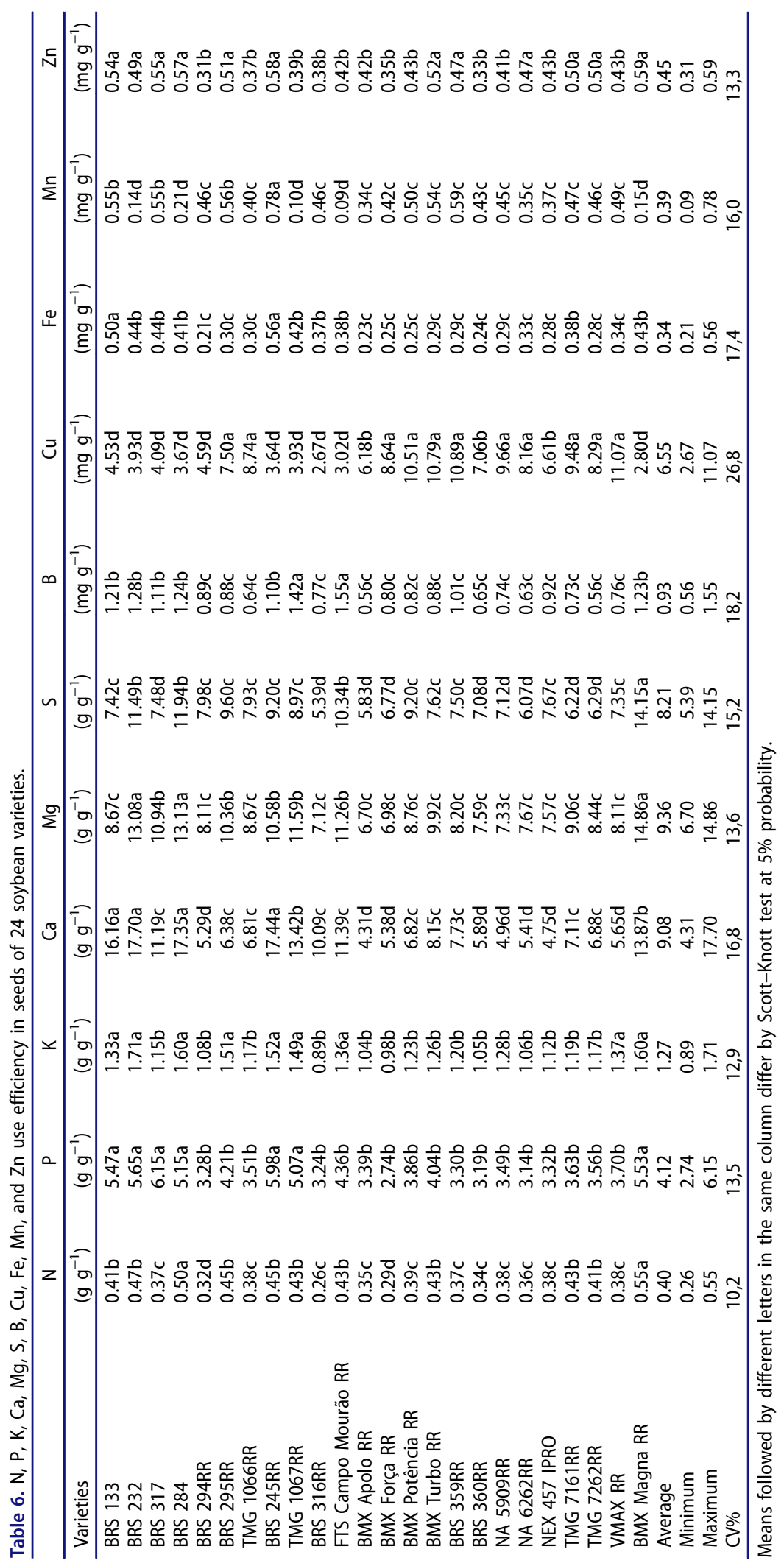




\section{Conclusions}

The selection of varieties and/or species of different agricultural characteristics, with higher concentration and greater nutrient uptake efficiency, can be an important alternative in the process of biofortification of food. Soybean is one of the most widely cultivated leguminous crops, being an important direct and indirect source of nutrients, including proteins and minerals. Great variability was observed in photosynthesis rate, chlorophyll content, seed yield (SY), and concentration and uptake of nutrients among the varieties. The NGM varieties had the highest $\mathrm{N}, \mathrm{Cu}$, and $\mathrm{Mn}$ concentrations and uptake (nutrient concentration in seed $\times$ seed weight per pot) of $\mathrm{N}, \mathrm{K}, \mathrm{Cu}, \mathrm{Fe}, \mathrm{Mn}$, and $\mathrm{Zn}$ in the seeds, while GM varieties had the highest Ca concentrations. Varieties BRS 284 and BMX Magna RR had the highest nutrients concentration in the group with the highest NUE; the opposite was observed for BRS 294RR, BMX Apolo RR, BMX Força RR, BMX Potência, BRS 360RR, and NEX 457 IPRO, demonstrating that the use of NUE can be an appropriate strategy in the selection of varieties with different nutrients concentrations in the seeds for use as biofortification of foods.

\section{Acknowledgments}

The authors acknowledge Concita Campelo from Embrapa Western Amazon (CPAA) for the laboratory analyses.

\section{Funding}

The authors acknowledge the National Counsel of Technological and Scientific Development (CNPq) for granting the Productivity Research Scholarship to the first author.

\section{References}

Allen, S. E., G. L. Terman, and L. B. Clements. 1976. Greenhouse techniques for soil-plant fertilizer research. Muscle Shoals, USA: Tennessee Valley Authority.

Anderson, J. J. B. 2003. Phosphorus/physiology. In Encyclopedia of food sciences and nutrition, ed. B. Caballero, L. T. Trugo, and P. M. Finglas, 4539-46. Waltham, USA: Academic Press.

Araújo, A. P., and M. G. Teixeira. 2012. Variability of nutrient harvest indices in common bean genotypes and their relationship with seed yield. Revista Brasileira de Ciência do Solo 36:137-46.

Bottrill, D. E., J. V. Possingham, and P. E. Kriedemann. 1970. The effect of nutrient deficiencies on photosynthesis and respiration in spinach. Plant and Soil 32:424-38. doi:10.1007/BF01372881.

Caballero, B., L. T. Trugo, and P. M. Finglas. 2003. Encyclopedia of food sciences and nutrition. Waltham, USA: Academic Press.

Casé, F., R. Deliza, A. Rosenthal, D. Mantovani, and I. Felberg. 2005. Production of calcium enriched soymilk. Ciência e Tecnologia de Alimentos 25:86-91. doi:10.1590/S0101-20612005000100014.

Cassel, D. K., and D. R. Nielsen. 1986. Field capacity and available water capacity. In Methods of soil analysis: Physical and mineralogical methods, ed. A. Klute, 901-26. Madison, USA: America Society of Agronomy.

Childs, N. M. 1995. Functional foods and market entry. The World of Ingredients 1:36-9.

EMBRAPA (Empresa Brasileira de Pesquisa Agropecuária). 1997. Manual of Soil Analysis Methods. 2nd ed. Rio de Janeiro: National Soil Research Center.

Fageria, N. K. 1998. Optimizing nutrient use efficiency in crop production. Revista Brasileira de Engenharia Agrícola e Ambiental 2:6-16.

Fageria, N. K., V. C. Baligar, and R. B. Clark. 2002. Micronutrients in crop production. Advances in Agronomy 77:85-268.

Fageria, N. K., M. P. Barbosa Filho, and A. Moreira. 2008. Screening upland rice genotypes for manganese-use efficiency. Communications in Soil Science and Plant Analysis 39:2873-82. doi:10.1080/00103620802432790.

Fageria, N. K., M. F. Moraes, E. P. B. Ferreira, and A. M. Knupp. 2012b. Biofortification of trace elements in food crops for human health. Communications in Soil Science and Plant Analysis 43:556-70. doi:10.1080/ 00103624.2012 .639431$.

Fageria, N. K., A. Moreira, C. Castro, and M. F. Moraes. 2013. Optimal acidity indices for soybean production in Brazilian Oxisols. Communications in Soil Science and Plant Analysis 44:2941-51. doi:10.1080/ 00103624.2013 .829484$.

Fageria, N. K., A. Moreira, and A. M. Coelho. 2012a. Nutrient uptake in dry bean genotypes. Communications in Soil Science and Plant Analysis 43:2289-302. doi:10.1080/00103624.2012.701689. 
Fairweather-Tait, S. J., and S. Southon. 2003. Bioavailability of nutrients. Norwich, UK: Elsevier Science.

Fehr, W. R., C. E. Caviness, D. T. Burmood, and J. S. Pennington. 1971. Stage of development descriptions for soybeans, Glycine max (L.) Merrill1. Crop Science 11:929-31. doi:10.2135/cropsci1971.0011183X001100060051x.

Fritschi, F. B., and J. D. Ray. 2007. Soybean leaf nitrogen, chlorophyll content, and chlorophyll a/b ratio. Photosynthetica 45:92-8. doi:10.1007/s11099-007-0014-4.

Griffin, I. J. 2003. Magnesium. In Encyclopedia of food sciences and nutrition, ed. B. Caballero, L. T. Trugo, and P. M. Finglas, 3641-6. Waltham, USA: Academic Press.

Hunt, C. D. 2003. Boron. In Encyclopedia of food sciences and nutrition, ed. B. Caballero, L. T. Trugo, and P. M. Finglas, 566-74. Waltham, USA: Academic Press.

Johnson, M. A. 2003. Copper/physiology. In Encyclopedia of food sciences and nutrition, ed. B. Caballero, L. T. Trugo, and P. M. Finglas, 1640-7. Waltham, USA: Academic Press.

Keen, C. L., and S. Zidenberg-Cherr. 2003. Manganese. In Encyclopedia of food sciences and nutrition, ed. B. Caballero, L. T. Trugo, and P. M. Finglas, 3686-91. Waltham, USA: Academic Press.

Klevay, L. M. 1980. Interaction of cooper and zinc in cardiovascular disease. In Micronutrient interactions: Vitamins minerals and hazardous elements, ed. O. A. Levander, and L. Cheng, 40-51. New York, USA: The New York Academy of Science.

Krishnan, H. B., S. Jang, W. S. Kim, M. S. Kerley, M. J. Oliver, and H. N. Trick. 2011. Biofortification of soybean meal: Immunological properties of the $27 \mathrm{kDa} \gamma$-Zein. Journal of Agricultural and Food Chemistry 59:1223-8. doi:10.1021/ jf103613s.

L'Abbé, M. R. 2003. Calcium/physiology. In Encyclopedia of food sciences and nutrition, ed. B. Caballero, L. T. Trugo, and P. M. Finglas, 771-9. Waltham, USA: Academic Press.

Levander, O. A., and L. Cheng. 1980. Micronutrient interactions: Vitamins minerals and hazardous elements. New York, USA: The New York Academy of Science.

Lynch, S. R. 2003. Iron/physiology. In Encyclopedia of food sciences and nutrition, ed. B. Caballero, L. T. Trugo, and P. M. Finglas, 3373-9. Waltham, USA: Academic Press.

Malavolta, E., G. C. Vitti, and S. A. Oliveira. 1997. Evaluation of nutritional status of plants; principles and application. Piracicaba, Brazil: Associação Brasileira para Pesquisa da Potassa e do Fosfato.

Moreira, A., N. K. Fageria, and A. Garcia Y Garcia. 2011. Effect of liming on the nutritional conditions and yield of alfalfa grown in tropical conditions. Journal of Plant Nutrition 34:1107-19. doi:10.1080/01904167.2011.558155.

Mounts, T. L., W. J. Wolf, and W. H. Martinez. 1987. Processing and utilization. In Soybeans: Improvement, production and uses, ed. J. R. Wilcox, 819-66. Madison, WI: American Society of Agronomy.

Navarro, M. P., and M. P. Vaquero. 2003. Potassium/physiology. In Encyclopedia of food sciences and nutrition, ed. B. Caballero, L. T. Trugo, and P. M. Finglas, 4650-8. Waltham, USA: Academic Press.

Ramamurthy, R. K., J. Jedlicka, G. L. Graef, and B. M. Waters. 2014. Identification of new QTLs for seed mineral, cysteine, and methionine concentrations in soybean [Glycine max (L.) Merr.]. Molecular Breeding 34:431-45. doi:10.1007/s11032-014-0045-z.

Rios, S. A. R., K. R. Alves, N. M. B. Costa, and H. S. D. Martino. 2009. Biofortification: Micronutrient enriched crops by genetic improvement. Revista Ceres 56:713-8.

Ruz, M. 2003. Zinc/properties and determination. In Encyclopedia of food sciences and nutrition, ed. B. Caballero, L. T. Trugo, and P. M. Finglas, 6272-7. Waltham, USA: Academic Press.

Scott, A. J., and M. A. A. Knott. 1974. A cluster analysis method for grouping means in the analysis of variance. Biometrics 30:507-12. doi:10.2307/2529204.

Siddiqi, M. Y., Y. Chyan, and F. G. Freiji. 1994. Utilization index: A modified approach to the estimation and comparison of nutrient utilization efficiency in plants. Journal of Plant Nutrition 4:289-302. doi:10.1080/ 01904168109362919.

Silva, M. S., M. M. V. Naves, R. B. Oliveira, and O. S. M. Leite. 2006. Chemical composition and protein value of the soybean residue in relation to the soybean grain. Ciência Tecnologia de Alimentos 26:571-6. doi:10.1590/S010120612006000300014.

Simão, A. N. C., D. S. Barbosa, L. B. Nunes, P. Godeny, M. A. B. Lozovoy, and I. Dichi. 2008. The importance of soy ingestion in postmenopausal symptoms, osteoporosis, and cardiovascular diseases. Arquivos de Ciência da Saúde da UNIPAR 12:67-75.

Sinclair, T. R. 1998. Historical changes in harvest index and crop nitrogen accumulation. Crop Science 38:638-43. doi:10.2135/cropsci1998.0011183X003800030002x.

Smith, K. J., and W. Huyser. 1987. World distribution and significance of soybean. In Soybeans: Improvement, production and uses, ed. J. R. Wilcox, 1-22. Madison, WI: American Society of Agronomy.

Taiz, L., and E. Zeiger. 2010. Plant physiology. New York, EUA: Sinauer Associates

USDA - United State Department of Agriculture. 2014. National Resources Conservation Service. Washington, DC: USDA.

Welch, R. M., and R. D. Graham. 2002. Breeding crops for enhanced micronutrient content. Plant and Soil 245:20514. doi:10.1023/A:1020668100330.

Welch, R. M., and R. D. Graham. 2004. Breeding for micronutrients in staple food crops from a human nutrition perspective. Journal of Experimental Botany 55:353-64. doi:10.1093/jxb/erh064. 